is really inconsistent with that of Uniformity is what Professor Huxley calls Evolutionism, and which I prefer to call Progression or Progressive Development. Even Mr. Huxley has, it seems to me, abused the similar word "Catastrophical" by taking it to indicate a "tertium quid," a theory as much opposed to Evolutionism as to Uniformitarianism. ${ }^{1}$ Whereas I conceive the idea of occasional Catastrophes or Paroxysms to be quite compatible with either theory.-Your obedient servant,

FaIRLAWN, CobHaM, Surkmy.

G. Poulett Scrope.

\title{
DISCOVERY OF FLINT-IMPLEMENTS NEAR FOLKESTONE, KENT.
}

SIR,-It may both interest some of your readers as well as stir up those dwelling in the neighbourhood to know that during the course of the last month, $I$ found at Folkestone several Flint-implements. Along the sides of the footpath on the top of the cliff between Folkestone and Sandown, there is a low embankment, made probably of material collected off the adjoining fields; in this embankment the implements occur. They are mostly of the rude flake or "scraper" pattern. The first discovered, which was also the finest, was lying partly exposed on the top of the bank, and subsequently my brother and myself found several more not far from the same spot. I enclose sketches of the principal ones, and I have little doubt that further search in the same bank would bring many others, and possibly finer ones, to light.-I am, etc.,

St. Thomas's Rectory, Brampton,

Cherterfield, Aug. 16, 1870.
J. M. MeLLo, M.A., F.G.S.

[Notz.-The locality referred to by the Rer. J. M. Mello is one of great interest and has been, we believe, already noticed by Mr. John Evans, F.R.S., Sec. Geol. Soc., Mr. W. Whitaker, F.G.S., and other gentlemen; by whom stone-implements have also been obtained thereabouts. A flint-tlake, corresponding with the largest found by Mr. Mello, is figured on Plate Ixvii. $\Delta$. of the "Reliquiz Aquitanica," by Mesers. Lartet and Christy. Figs. 4 and 5 of $\mathrm{Mr}$. Mello's sketch resemble a "Flint piercer" from La Madelaine (Op. cit. woodeut fig. 62, p. 134, Part X) and an "Awl or Graver" (fig 23, p. 130. op. cit.). Both in Kent and Sussex, a large manufactory of flint-implements was undaubtedly carried on in prehistoric times,-EDIT. GBOI. Mae.

\section{HALL'S MINERALOGISTS' DIRECTORY.}

SIn,-In your notice of Hall's Mineralogists' Directory in the August Number of the Gronogiond M MaAzine, p. 382, you express a hope that information as to omissions and errors will be liberally responded to by local collectors so that the new edition promised by the anthor may be more complete and accurate than the present one. Having used Mr. Hall's book for some time I have great pleasure in testifying to its general accuracy, at the same time I venture to offer a few notes on one district (Cornwall) with which I am well acquainted, which, perhaps, may be useful to some of your readers snd also to Mr. Hall.

1 Anniversary Address to Geol. Soc., 1869. 
At Huel Bassett the occurrence of 'Cassiterite' is omitted; at Pengelly of 'Millerite.'

At Stenna Gwynn 'Wavellite' is named in mistake for 'Tavistockite' (vide new edition of Dana).

The occurrence of 'Senarmontite' is not mentioned at Endellion. ' Uranochre' has never been found at the Royal Restormel iron mines, but only the 'Bismuthochre,' while 'Restormelite' is omitted.

Several important mines have been overlooked entirely, e.g., 'Silver Vein,' near Lostwithiel, in which is found Argentiferous Tetrahedrite; the 'St. Austell Consols,' producing Chalcopyrite, Kupfernickel, Cobalt, and Pitchblende; and 'Lanescot' or 'Fowey Consols,' in which occur Chalcopyrite, Chalcotrichite, Magnetite, Chalybite, Cassiterite (Wood-tin), Kupfernickel, Cobalt, Bismuthine, Millerite, Melaconite.

I would ask Mr. Hall why he uses the namo 'Towanite' throughout his book instead of 'Chalcopyrite,' or Copper Pyrites, as the names are not synonymous, the former having been given by Greg and Lettsom to the modification found at Huel Towan; and also why he calls 'Limonite,' 'Limnite.' Limonite is derived from the Greek $\lambda \epsilon \iota \mu \omega \nu, a$ meadow, and is almost exclusively applied to the Brown Iron Ores; while 'Limnite,' from $\lambda i \mu \nu \eta$, a marsh, is applied to the Yellow and Stalachtitic bog iron ores. To these varieties are given distinct formulæ in Dana's last edition, and, therefore, they may be regarded as species for the present.

Apologizing for intruding on your valuable space I am, etc.,

Brackiey, August 22, 1870.

B. J. R.

\section{MISCEIIANEOUS.}

New British Locality for Avantorine-Qdartz.-This soarce variety of quartz has recently been observed by Mr. G. W. Traill in Orkney, on the S. and S.W. shores of Inganess Bay. It occurs in the form of small rolled pebbles, seldom exceeding an inch in diameter, but well marked, and occasionally fit for ornamental purposes. The colour is usually reddish-brown, but sometimes yellow. The scales of mica are very numerous, of a golden colour, small, uniform in size, and generally disposed in parallel planes as if they had settled in a liquid; but in a few of the specimens this regular arrangement does not appear. The reddish-brown variety is very compact, takes a high polish, and has a specific gravity of 2.62 ; the yellow is of a fine granular structure, and has a specific gravity of 2.60. This appears to be almost the only well-ascertained British locality for avanturine-quartz; and, as the rocks in the neighbourhood are entirely sandstone, the situation is somewhat peculiar.

The Congress of Alpine Grologists which was to have been held at Geneva, on 31st August and the 1st and 2nd September, is indefinitely postponed, owing to the present unsettled state of Europe. 